\title{
High TWIST1 mRNA expression is associated with poor prognosis in lymph node-negative and estrogen receptor-positive human breast cancer and is co-expressed with stromal as well as ECM related genes
}

Muhammad Riaz, Anieta M Sieuwerts, Maxime P Look, Mieke A Timmermans, Marcel Smid, John A Foekens and John WM Martens ${ }^{*}$

\begin{abstract}
Introduction: The TWIST homolog 1 (TWIST1) is a transcription factor that induces epithelial to mesenchymal transition (EMT), a key process in metastasis. The purpose of this study was to investigate whether TWIST1 expression predicts disease progression in a large breast cancer cohort with long-term clinical follow-up, and to reveal the biology related to TWIST1 mediated disease progression.
\end{abstract}

Methods: TWIST1 mRNA expression level was analyzed by quantitative real-time reverse polymerase chain reaction (RT-PCR) in 1,427 primary breast cancers. In uni- and multivariate analysis using Cox regression, TWIST1 mRNA expression level was associated with metastasis-free survival (MFS), disease-free survival (DFS) and overall survival (OS). Separate analyses in lymph node-negative patients $(L N N, n=778)$ who did not receive adjuvant systemic therapy, before and after stratification into estrogen receptor (ER)-positive $(n=552)$ and ER-negative $(n=226)$ disease, were also performed. The association of TWIST1 mRNA with survival endpoints was assessed using KaplanMeier analysis. Using gene expression arrays, genes showing a significant Spearman rank correlation with TWIST1 were used to identify overrepresented Gene Ontology (GO) terms and Kyoto Encyclopedia of Genes and Genomes (KEGG)-annotated biological pathways.

Results: Increased mRNA expression level of TWIST1 analyzed as a continuous variable in both uni- and multivariate analysis was associated with shorter MFS in all patients (hazard ratio (HR): 1.17, 95\% confidence interval, (95\% Cl):1.09 to 1.26; and HR: 1.17, 95\% Cl: 1.08 to 1.26; respectively), in LNN patients (HR: 1.22, 95\% Cl: 1.09 to 1.36; and HR: $1.21,95 \% \mathrm{Cl}: 1.07$ to 1.36; respectively) and in the ER-positive subgroup of LNN patients (HR: 1.34, 95\% Cl: 1.17 to 1.53; and HR: 1.32, 95\% Cl: 1.14 to 1.53; respectively). Similarly, high TWIST1 expression was associated with shorter DFS and OS in all patients and in the LNN/ER-positive subgroup. In contrast, no association of TWIST1 mRNA expression with MFS, DFS or OS was observed in ER-negative patients. Genes highly correlated with TWIST1 were significantly enriched for cell adhesion and ECM-related signaling pathways. Furthermore, TWIST1 mRNA was highly expressed in tumor stroma and positively related to tumor stromal content $(P<0.001)$.

Conclusions: TWIST1 mRNA expression is an independent prognostic factor for poor prognosis in LNN/ER-positive breast cancer. The biological associations suggest an involvement of the tumor microenvironment in TWIST1's adverse role in breast cancer.

\footnotetext{
*Correspondence: j.martens@erasmusmc.nl

Erasmus University Medical Center - Daniel den Hoed Cancer Center,

Department of Medical Oncology and Cancer Genomics Center, Rotterdam,

The Netherlands
} 
Keywords: TWIST1, Breast cancer, mRNA expression, Prognosis, Nodal status, Estrogen receptor, Metastasis-free survival, Stroma

\section{Introduction}

Breast cancer is one of the most frequently diagnosed cancers and the leading cause of cancer related deaths among females of the Western world [1]. Patients do not die from the primary tumor, but from metastases, which already are resistant or acquire resistance to systemic therapy. Metastasis is a complex, multi-step process in which malignant cells undergo sequential molecular changes helping them to disengage from primary sites, intravasate into blood vessels, extravasate to distant organs and finally colonize secondary sites. Each of these metastatic steps is affected by aberrant expression of a variety of transcription factors and among them, TWIST homologue 1 (TWIST1) is considered an important regulator of disease progression [2].

The TWIST1 protein, encoded by the TWIST1 gene, is a member of a large protein family called basic helixloop-helix (bHLH) transcription factors [3]. Most family members contain a bHLH domain, which enables it to target specific DNA sequences and thereby allowing them to regulate developmental processes in many organs and tissues. TWIST1 plays a key role in the regulation of embryogenesis, gastrulation and mesoderm formation during early embryonic development of Drosophila and many other species $[4,5]$. An autosomal mutation pattern in the TWIST1 gene leads to SaethreChotzen syndrome, a genetic condition characterized by premature fusion of skull bones affecting symmetrical growth of the head and face [6]. In children, TWIST1 protein is involved in adequate maturation of the skull and spine bones and normal development of arms and hind legs.

More recently, TWIST1 protein has been implicated in various carcinomas, including breast cancer, where it plays a role in metastasis through activation of a biologically latent developmental process called epithelial to mesenchymal transition (EMT) $[7,8]$. In the EMT process, malignant epithelial cells undergo cytoskeletal changes, including the down-regulation of epithelial markers, such as E-cadherin and co-expressed catenins and up-regulation of mesenchymal markers, such as vimentin, $\mathrm{N}$-cadherin and fibronectin. EMT transformed malignant cells are more motile and can be more efficient in invading the surrounding tissues and as a result metastasize to distant organs [9].

In this large retrospective study of 1,427 primary breast cancer patients, we determined whether the TWIST1 gene expression level is a prognostic marker. To avoid possible confounding effects of therapy and to study the natural course of the disease, we particularly focused on the subgroup of 778 lymph node-negative (LNN) patients who did not receive any adjuvant systemic therapy. Additionally, to understand the biological context of TWIST1, we have identified, using available Affymetrix U133A gene expression data $[10,11]$, genes and biological pathways co-expressed with TWIST1. By doing this, we identified a clear link between the tumor microenvironment and TWIST1 expression in clinical breast cancer.

\section{Methods}

\section{Patients}

This study was approved by the institutional medical ethics committee of the Erasmus MC (MEC 02.953). The study was performed in accordance with the Code of Conduct of the Federation of Medical Scientific Societies in The Netherlands [12]; informed consent was not required. Wherever possible, the study has been reported in line with the Reporting Recommendations for Tumor Marker Prognostic Studies guidelines [13,14]. Breast cancer tissue specimens from 1,427 female patients with primary operable breast cancer were included in the study. Tumor samples were originally submitted to our reference laboratory from 25 regional hospitals for biochemical assessment of steroid hormone receptor status. Guidelines for primary treatment were similar in all hospitals. All available frozen breast tumor samples of at least $100 \mathrm{mg}$ from female patients with invasive breast cancer who entered the clinic during the period of 1978 to 2001, and from whom detailed clinical follow-up data were available were processed. Moreover, these patients had no distant metastasis within the first month after primary surgery and no prior cancer except basal skin carcinoma and cervical cancer stage I. ER, PGR and HER2 (ERBB2) levels were assessed by quantitative real-time reverse transcriptase PCR (qRTPCR) as described before [15-17]. Lymph node involvement, tumor size and grade were extracted from the pathology reports as obtained from the hospitals. Primary surgical treatment was lumpectomy in 628 patients (44\%) or modified mastectomy for 799 patients (56\%). One thousand and nine patients (71\%) received adjuvant radiotherapy at the thoracic wall only $(n=639)$ and either at the thoracic wall and nodal stations $(n=290)$ or at the nodal stations only $(n=80)$. Thirty-three percent of the patients had T1 tumors. The median age of the patients at surgery was 55 years (range, 23 to 89 years). Routine post-surgical follow-up and the definition of the endpoints of MFS, DFS and OS were described before $[11,18]$. During follow-up, a local/regional relapse for 127 patients was not counted as 
an event in the analysis of MFS. The median follow-up time was 104 months (range, 4 to 262 months) with 707 and 669 events in the analyses of MFS and OS, respectively. Study design, patient inclusion criteria and patient subgroups included in the analyses are given in Figure 1. Other relevant clinico-pathological characteristics are listed in Table 1.

Tissue processing and estimation of the amount of epithelial tumor cells

Tissue processing was done as described in detail previously $[15,19]$. In brief, 20 to 60 cryostat sections of $30 \mu \mathrm{m}$ size corresponding to 30 to $100 \mathrm{mg}$ weight were cut from frozen tissues. Three $5 \mu \mathrm{m}$ sections were cut before, in between and after cutting the sections for RNA isolation, and were stained with hematoxylin and eosin (H\&E) to assess the amount of tumor cells relative to the amount of surrounding stromal cells. The amount of nuclei evidently of epithelial tumor cell origin relative to the amount of surrounding stromal cells was estimated with a 100-fold magnification in 10 different areas covering the area of each of the three H\&E sections. Only specimens with at least $30 \%$ of the nuclei of epithelial tumor cell origin and distributed uniformly over at least $70 \%$ of the section area were included. Like before [16], these estimates were used to dichotomize our tumor cohort at the

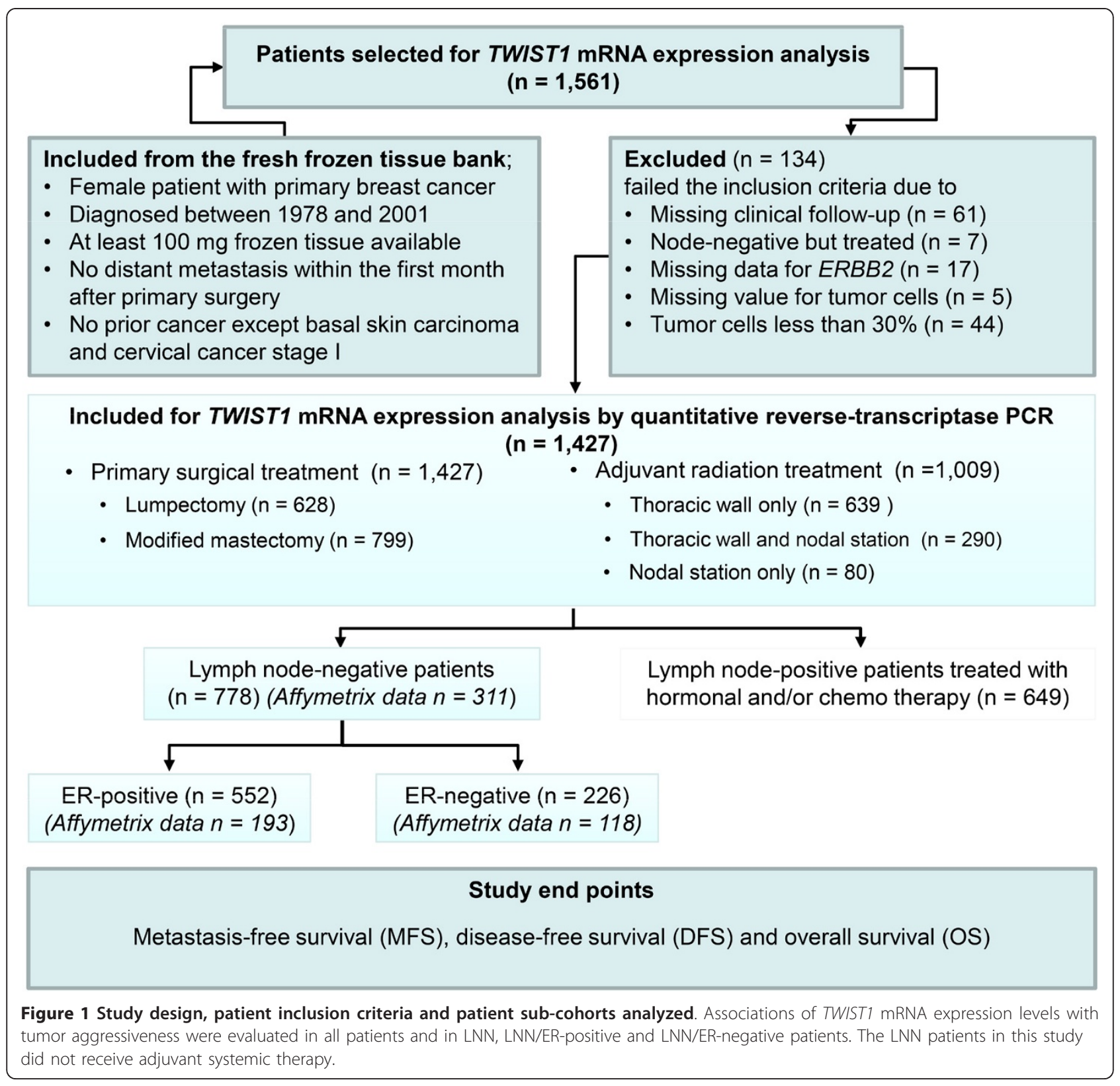


Table 1 Association of TWIST1 mRNA expression with standard clinical and pathological characteristics of patients and tumors

\begin{tabular}{|c|c|c|c|}
\hline Characteristics & No. patients & TWIST1 mRNA expression (Median value*) & $P$-value \\
\hline \multicolumn{4}{|l|}{ Age (years) } \\
\hline$\leq 40$ & 188 & 0.025 & \\
\hline 41 to 55 & 530 & 0.028 & \\
\hline 56 to 70 & 471 & 0.030 & \\
\hline$>70$ & 238 & 0.020 & $0.04^{+}$ \\
\hline \multicolumn{4}{|c|}{ Menopausal status } \\
\hline Premenopausal & 603 & 0.027 & \\
\hline Postmenopausal & 824 & 0.027 & $0.21^{\ddagger}$ \\
\hline \multicolumn{4}{|l|}{ Tumor size } \\
\hline $\mathrm{pT} 1, \leq 2 \mathrm{~cm}$ & 463 & 0.031 & \\
\hline pT2, $>2$ to $\leq 5$ & 807 & 0.025 & \\
\hline pT3, $>5+$ pT4 & 157 & 0.028 & $0.009^{n}$ \\
\hline \multicolumn{4}{|c|}{ Lymph nodes involved } \\
\hline 0 & 778 & 0.026 & \\
\hline 1 to 3 & 288 & 0.025 & \\
\hline$>3$ & 361 & 0.030 & $0.007^{\natural}$ \\
\hline \multicolumn{4}{|l|}{ Grade } \\
\hline Poor & 800 & 0.026 & \\
\hline Good/Moderate & 230 & 0.027 & \\
\hline Unknown & 397 & 0.029 & $0.47^{\natural}$ \\
\hline \multicolumn{4}{|l|}{ Tumor histology } \\
\hline IDC & 957 & 0.027 & \\
\hline ILC & 112 & 0.044 & $<0.001^{\neq, \S}$ \\
\hline Medullary & 31 & 0.016 & \\
\hline Mucinous & 39 & 0.008 & $<0.001^{\natural}$ \\
\hline \multicolumn{4}{|l|}{ ER status (mRNA) } \\
\hline Negative & 360 & 0.021 & \\
\hline Positive & 1,067 & 0.029 & $0.06^{\dagger}$ \\
\hline \multicolumn{4}{|c|}{ PGR status (mRNA) } \\
\hline Negative & 572 & 0.023 & \\
\hline Positive & 855 & 0.029 & $<0.001^{\dagger}$ \\
\hline \multicolumn{4}{|c|}{ ERBB2 status (mRNA) } \\
\hline Negative & 1,187 & 0.026 & \\
\hline Positive & 240 & 0.032 & $<0.001^{\dagger}$ \\
\hline
\end{tabular}

Abbreviations: IDC, invasive ductal carcinoma; ILC, invasive lobular carcinoma.

* Expression values after normalization to our set of three reference genes (B2M, HMBS and HPRT1).

$+P$ Spearman rank correlation test.

$\neq P$ for Mann-Whitney test.

१ $P$ for Kruskal-Wallis test.

$\S$ TWIST1 expression was compared between IDC and ILC tumors.

median level of $70 \%$ tumor cell nuclei in stromal-rich (SR) (primary tumors containing $\geq 30 \%$ stromal components) and stromal-poor (SP) (primary tumors containing at least $70 \%$ tumor cells).

RNA isolation, CDNA synthesis, and quantification of specific mRNA species

RNA isolation, cDNA synthesis, quantification of specific mRNA species and quality control checks were done as described previously by Sieuwerts et al. [15]. qRT-PCR was performed in $25-\mu \mathrm{l}$ reaction volume in a Mx3000P Real-time PCR System (Agilent, Amsterdam, The Netherlands) using a commercially available gene expression assay for TWIST1 (Hs00361186_m1) and for VIM (Hs Hs00185584_m1) from Applied Biosystems/Life Technologies (Nieuwerkerk aan den IJssel, The Netherlands). For EPCAM mRNA measurement, a combination of the following primers and probe was used (F: 3'-AGT TTG CGG ACT GCA CTT CA, R: 3'- AAT ACT CGT GAT AAA TTT TGG ATC CA, FAM-labeled MGB probe: 
AAG GAG ATC ACA ACG CGT). Primer sequences for estrogen receptor- $\alpha$ (ESR1), progesterone receptor $(P G R), E R B B 2$ and the reference genes (HMBS, HPRT1 and $B 2 M$ ), as well as how PCR reactions and validations were carried out to ensure PCR specificity, were done as described before $[15,17]$. Levels of mRNA expression were quantified relative to the set of reference genes as described before [15].

\section{Laser capture microdissection}

Laser capture microdissection (LCM) was performed according to a previously published method [20]. Briefly, 8 $\mu \mathrm{m}$ sections of fresh frozen tumor tissue were cryosectioned and pasted on UV sterilized polyethylene naphthalate (PEN) covered glass slides (P.A.L.M. Microlaser Technologies, Bernried, Germany). The slides were air dried for $10 \mathrm{sec}$ at room temperature, fixed in ice-cold $70 \%$ ethanol and washed shortly in Milli-Q water. The slides were then stained for $15 \mathrm{sec}$ in Haematoxylin (Klinipath 4085.9005, Duiven, The Netherlands) and washed again in Milli-Q water. Subsequently, the slides were dehydrated twice in RNase-free 50, 70, 95 and 100\% ethanol for $30 \mathrm{sec}$ each, and air-dried. Next, LCM was performed directly on the stained sections. From consecutive cryosections of a tumor tissue, both the stromal content and tumor epithelial cells were collected separately in triplicate in P.A.L.M. tube caps containing $25 \mu \mathrm{l}$ of tissue lysis (RLT +) buffer (Qiagen 1053393, Venlo, The Netherlands) using a P.A.L.M. LCM device, type P-MB (P.A.L.M. Microlaser Technologies AG). Both stromal and epithelial cell fractions were then spun down into 0.5-ml Eppendorf Protein LoBind tubes (Eppendorf, Hamburg, Germany) containing $225 \mu \mathrm{l}$ RT + buffer and used for RNA isolation.

\section{Immunohistochemistry (IHC)}

Sections of $4 \mu \mathrm{m}$ were cut from formalin-fixed paraffinembedded tissues, pasted on glass slides and dried overnight at $37^{\circ} \mathrm{C}$. The slides were dewaxed in xylene solution and hydrated in a series of different percentages of alcohol (100\%, 95\%, 75\% and 50\%). The antigen was retrieved for 40 minutes in a hot water bath $\left(\right.$ at $\left.95^{\circ} \mathrm{C}\right)$ in Tris-EDTA buffer, pH 9.0 (DAKO; S2367, Glostrup, Denmark) and cooled for 20 minutes at room temperature. After retrieval, slides were immersed in 3\% hydrogen peroxide for 10 minutes to block endogenous peroxidase activity, and in a DAKO protein-free serum blocking solution for 30 minutes to block non-specific binding sites. The slides were then incubated overnight at $4^{\circ} \mathrm{C}$ with a mouse monoclonal primary antibody raised against a human recombinant fragment of TWIST1 (AbCam TWIST2C1a, ab50887, Cambridge, UK) and diluted 1:100 in an antibody diluent (DAKO). Negative controls were made by replacing the primary antibody with mouse immunoglobulin at an appropriate dilution.
Next, the slides were treated with a secondary antibody (envision mouse kit, DAKO) and visualized using DAB (envision kit, DAKO). The slides were counterstained with hematoxylin and dehydrated through graded alcohol and xylene. Evaluation of the immunostaining and histoscoring were performed according to a previously published method [21]. Briefly, a histoscore of 0 to 300 was given to each tumor by multiplying the proportion of cells with nuclear staining in a tissue by the intensity of the staining as follows; histoscore $=(0 \times$ percentage not stained $)+(1 \times$ percentage weakly stained $)+(2 \times$ percentage moderately stained $)+(3 \times$ percentage strongly stained). The histoscores calculated in this way were correlated with TWIST1 mRNA expression. The intensity of TWIST1 stromal expression in tumor tissues was scored as no, weak, moderate or strong staining.

\section{Identification of TWIST1 co-expressed genes on Affymetrix U133A gene-chips and identification of Gene Ontology (GO) terms and biological pathways}

In this analysis we used TWIST1 mRNA expression, which was previously measured by Affymetrix U133A gene-chips (Affymetrix, Santa Clara, CA, USA) (probe set 213943_at) $[10,11,22]$. The mRNA expression levels of TWIST1 measured on the Affymetrix-array and by qRTPCR were highly correlated in an overlap of 193 LNN/ ER-positive and 118 LNN/ER-negative tumor specimens using the Spearman-Rank correlation test (Spearman rank correlation, Rs $=0.7 ; P<0.001$ for both). Genes showing a significant positive or negative correlation with TWIST1 were identified by using these Affymetrixarray data after all genes were corrected for multiple testing by applying a false discovery rate (FDR) of 5\% [23]. Biological pathways and GO terms from genes significantly co-expressed with TWIST1 were identified using the ArrayTrack ${ }^{\mathrm{TM}}$ software (NCTR/FDA, Jefferson, AR 72079, USA) [24]. The overrepresented pathways and GO terms identified by ArrayTrack ${ }^{\mathrm{TM}}$ were based on Fisher's exact statistics. Details about how ArrayTrack ${ }^{\mathrm{TM}}$ software functions can be retrieved from the website [25]. The gene expression data used have previously been deposited in the National Center for Biotechnology Information/Gene Expression Omnibus database entries GSE2034 and GSE5327.

\section{Statistics}

Computations were done with the use of the STATA statistical package, release 11.2 (STATA Corp., College Station, TX, USA). Differences in levels were assessed with the Mann-Whitney U test or Kruskal-Wallis test. In these tests, patient and tumor characteristics were used as grouping variables. The strengths of the associations between continuous variables were tested with the Spearman rank correlation test. TWIST1 mRNA expression 
levels measured by qRT-PCR were log transformed to reduce the skewness (Skewness-Kurtosis normality test, $P<0.05)$ and to attain symmetric distribution (Additional file 1: Figure S1). The prognostic value of the clinical and biological variables, with MFS, OS and DFS as the end points in the univariate and multivariate analyses, were investigated with the use of the Cox proportional hazard model. The hazard ratio (HR) and its 95\% confidence interval $(95 \% \mathrm{CI})$ were derived from these models by analyzing TWIST1 mRNA expression levels as a continuous variable or after dividing their levels into quartiles. The proportionality assumption was investigated with a test based on the Schoenfeld residuals. Kaplan-Meier survival analysis was performed and a log-rank test was used to assess a trend of survivor's function across four quartiles of TWIST1 mRNA expression levels. All $P$-values are twosided, and $P<0.05$ was considered statistically significant.

\section{Results}

\section{Association of TWIST1 mRNA expression with standard clinical and pathological characteristics of patients and tumors}

Association of TWIST1 mRNA expression levels with clinical and pathological characteristics of patients and tumors are shown in Table 1. Tumor TWIST1 mRNA expression was higher in patients with $>3$ positive lymph nodes, and lower in pT2 tumors and in older patients. Furthermore, TWIST1 mRNA expression was higher in invasive lobular carcinoma (ILC) compared with invasive ductal carcinoma (IDC). Mucinous and medullary-type of tumors showed the lowest TWIST1 mRNA expression levels. In addition, TWIST1 mRNA expression level was higher in $P G R$-positive and ERBB2-overexpressing tumors, but was not associated with tumor grade and menopausal status.

\section{Association of TWIST1 mRNA expression with prognosis in primary breast cancer patients}

To explore the prognostic significance of TWIST1 mRNA expression in primary breast cancer patients, we first performed Cox uni- and multivariate analyses (traditional factors in the multivariate analysis were; age, menopausal status, number of positive lymph nodes, tumor size, tumor grade, ER status, PGR status and ERBB2 status) for MFS, DFS and OS as a function of continuous TWIST1 mRNA expression levels. In all 1,427 patients, increasing TWIST1 mRNA expression levels was associated with shorter MFS in both uniand multivariate analysis (HR: $1.17,95 \%$ CI: 1.09 to 1.26; $P<0.001$ and HR: $1.17,95 \%$ CI: 1.08 to 1.26 ; $P<0.001$; respectively) (Table 2 ). To visualize the prognostic value of TWIST1 mRNA expression in KaplanMeier survival curves, we divided TWIST1 expression levels into four quartiles Q1 (low) to Q4 (high) (Figure 2).
To exclude a possible confounding treatment effect, we also evaluated the prognostic value of TWIST1 mRNA expression in LNN-patients who did not receive any adjuvant systemic therapy. We also stratified these LNN patients into ER-positive and ER-negative subgroups as these subgroups are considered biologically distinct. In the analysis of all $778 \mathrm{LNN}$ patients, an association of increasing TWIST1 mRNA expression levels with shorter MFS was observed in both uni- and multivariate analysis (univariate HR: $1.22,95 \%$ CI: 1.09 to $1.36 ; P=0.001$ and HR: $1.21,95 \%$ CI: 1.07 to 1.36 ; $P=0.001$; respectively) (Additional file 2: Table S1). Moreover, within the LNN subgroup of patients, the association of increasing TWIST1 mRNA levels with shorter MFS was confined to the ERpositive subgroup of patients (univariate (HR: 1.34, 95\% CI: 1.17 to $1.53 ; P<0.001$ ) and multivariate (HR: $1.32,95 \%$ CI: 1.14 to $1.53 ; P<0.001)$ ) (Table 3 ). There was no association of TWIST1 mRNA levels with MFS in the ERnegative subgroup of patients (univariate $\mathrm{HR}=1.05$, 95\% CI: 0.86 to $1.29 ; P=0.64$ ) (Additional file 2: Table S2). Kaplan-Meier survival curves for all patients and subgroups of patients with LNN and LNN/ER-positive and LNN/ER-negative disease, after dividing these cohorts in quartiles (Q1 to Q4), are shown in Figure 2A-D. Cox regression analysis for MFS showed that in the LNN/ERpositive group the quartile with the highest TWIST1 mRNA levels (Q4) had a two-fold increased hazard ratio compared with the quartile with the lowest TWIST1 mRNA levels (Q1) (Table 3).

We also related TWIST1 mRNA expression levels with OS in all patients, in the LNN cases as a whole and after stratifying by ER status. Similarly as observed for MFS, increasing TWIST1 mRNA expression levels was associated with shorter OS in all patients (univariate HR: 1.10, $95 \%$ CI: 1.08 to $1.26, P=0.013$; multivariate HR: $1.11,95 \%$ CI: 1.03 to $1.20, P=0.006$ ), in the LNN (univariate $\mathrm{HR}: 1.13,95 \% \mathrm{CI}$ : 1.01 to $1.27, P=0.03$; multivariate HR: $1.16,95 \% \mathrm{CI}: 1.03$ to $1.30, P=0.01)$ and in the LNN/ER-positive group of patients (univariate HR: 1.26, 95\% CI: 1.09 to $1.45, P=0.001$; multivariate HR: 1.27 , 95\% CI: 1.11 to $1.46, P=0.001)$. These associations were not significant in the LNN/ER-negative group of patients (univariate HR: $0.96,95 \% \mathrm{CI}: 0.78$ to $1.18, P=0.69$; multivariate HR: $0.98,95 \% \mathrm{CI}: 0.79$ to $1.21, P=0.85)$. The results are included in Additional file 2: Tables S3-S6. Kaplan-Meier survival curves showing OS for all patients, and also for the subgroups of patients after dividing them into quartiles based on TWIST1 mRNA levels are shown in Additional file 1: Figure S2A-D.

We finally analyzed whether TWIST1 mRNA expression levels were associated with DFS in all patients and in LNN/ER-positive patients only, and obtained similar results as were obtained for MFS and OS (Additional file 2: Tables S7-8). 
Table 2 Model for uni-and multivariate analysis for metastasis-free survival in all patients $(n=1,427)$

\begin{tabular}{|c|c|c|c|c|c|c|c|}
\hline \multirow[t]{2}{*}{ Factors } & \multirow[t]{2}{*}{ No. patients } & \multicolumn{3}{|c|}{ Univariate } & \multicolumn{3}{|c|}{ Multivariate } \\
\hline & & HR & $95 \% \mathrm{Cl}$ & $P$-value & $\mathrm{HR}$ & $95 \% \mathrm{Cl}$ & $P$-value \\
\hline \multicolumn{8}{|l|}{ Age (years) } \\
\hline$\leq 40$ & 188 & 1 & & & 1 & & \\
\hline 41 to 55 & 530 & 0.92 & 0.73 to 1.16 & 0.47 & 0.88 & 0.69 to 1.12 & 0.30 \\
\hline 56 to 70 & 471 & 1.02 & 0.80 to 1.29 & 0.88 & 0.85 & 0.59 to 1.21 & 0.36 \\
\hline$>70$ & 238 & 0.80 & 0.66 to 1.06 & 0.12 & 0.69 & 0.47 to 1.03 & 0.07 \\
\hline \multicolumn{8}{|l|}{ Menopausal status } \\
\hline Premenopausal & 603 & 1 & & & 1 & & \\
\hline Postmenopausal & 824 & 1.07 & 0.92 to 1.25 & 0.35 & 1.23 & 0.94 to 1.62 & 0.14 \\
\hline \multicolumn{8}{|l|}{ Tumor size } \\
\hline $\mathrm{p} T 1, \leq 2 \mathrm{~cm}$ & 463 & 1 & & & 1 & & \\
\hline $\mathrm{pT} 2,>2$ to $\leq 5$ & 807 & 1.65 & 1.39 to 1.97 & $<0.001$ & 1.38 & 1.15 to 1.65 & $<0.001$ \\
\hline $\mathrm{pT} 3,>5+\mathrm{pT} 4$ & 157 & 2.80 & 2.20 to 3.58 & $<0.001$ & 1.80 & 1.39 to 2.33 & $<0.001$ \\
\hline \multicolumn{8}{|l|}{ Lymph nodes involved } \\
\hline 0 & 778 & 1 & & & 1 & & \\
\hline 1 to 3 & 288 & 1.79 & 1.48 to 2.17 & $<0.001$ & 1.71 & 1.41 to 2.08 & $<0.001$ \\
\hline$>3$ & 361 & 2.92 & 2.46 to 3.46 & $<0.001$ & 2.63 & 2.19 to 3.16 & $<0.001$ \\
\hline \multicolumn{8}{|l|}{ Grade } \\
\hline Poor & 800 & 1 & & & 1 & & \\
\hline Good/Moderate & 230 & 0.51 & 0.40 to 0.65 & $<0.001$ & 0.64 & 0.50 to 0.82 & $<0.001$ \\
\hline Unknown & 397 & 0.89 & 0.75 to 1.05 & 0.17 & 0.99 & 0.83 to 1.17 & 0.87 \\
\hline \multicolumn{8}{|l|}{ ER status (mRNA) } \\
\hline Negative & 360 & 1 & & & 1 & & \\
\hline Positive & 1,067 & 0.82 & 0.70 to 0.97 & 0.02 & 0.83 & 0.67 to 1.04 & $<0.001$ \\
\hline \multicolumn{8}{|l|}{ PGR status (mRNA) } \\
\hline Negative & 572 & 1 & & & 1 & & \\
\hline Positive & 855 & 0.75 & 0.64 to 0.87 & $<0.001$ & 0.87 & 0.71 to 1.06 & 0.17 \\
\hline \multicolumn{8}{|l|}{ ERBB2 status (mRNA) } \\
\hline Negative & 1,187 & 1 & & & 1 & & \\
\hline \multirow[t]{2}{*}{ Positive } & 240 & 1.30 & 1.08 to 1.57 & 0.006 & 1.18 & 0.97 to 1.43 & 0.09 \\
\hline & & & & & \multicolumn{3}{|c|}{ Addition to the base model } \\
\hline TWIST1 mRNA level ${ }^{\dagger}$ (Continuous) & 1,427 & 1.17 & 1.09 to 1.26 & $<0.001$ & 1.17 & 1.08 to 1.26 & $<0.001$ \\
\hline \multicolumn{8}{|l|}{ TWIST1 mRNA level ${ }^{\dagger}$} \\
\hline TWIST1 quartile 1 & 360 & 1 & & & 1 & & \\
\hline TWIST1 quartile 2 & 355 & 1.16 & 0.94 to 1.45 & 0.17 & 1.09 & 0.88 to 1.37 & 0.43 \\
\hline TWIST1 quartile 3 & 357 & 1.22 & 0.98 to 1.51 & 0.08 & 1.25 & 1.00 to 1.56 & 0.05 \\
\hline TWIST1 quartile 4 & 355 & 1.49 & 1.20 to 1.83 & $<0.001$ & 1.43 & 1.15 to 1.77 & 0.001 \\
\hline
\end{tabular}

TTWIST1 mRNA expression level (log-transformed after normalization to the expression of three reference genes) was separately added to the base multivariate model that included the factors age, menopausal status, tumor size, grade, lymph-node status, ER, PGR, and ERBB2 mRNA expression levels, tested both as a continuous variable and in four quartiles.

\section{Investigation of TWIST1 related biological pathways in LNN breast cancer}

To explore the underlying biology of TWIST1-associated disease progression in breast cancer, we determined TWIST1 co-expressed genes previously measured on Affymetrix U133A gene-chips [10,11]. Since we found TWIST1 to be associated with poor prognosis in LNN/ER-positive patients only, we first decided to include only the LNN/ ER-positive samples to examine the TWIST1 co-expressed genes. After using a Spearman correlation test followed by applying a multiple testing correction at a FDR of 5\%, we found 1,847 genes to be positively correlated and 1,445 genes to be negatively correlated with TWIST1 mRNA expression (Additional file 3: Table S9A, B). To reveal which biological pathways might be associated with TWIST1 mRNA expression, we performed pathway analyses using the genes co-expressed with TWIST1 and the KEGG pathway database as input for the analysis in the ArrayTrack $^{\mathrm{TM}}$ software package. The three most significantly overrepresented pathways containing these TWIST1 co-expressed genes were: Focal adhesion pathway (Fisher's exact $P=1.0 \times 10^{-8}$ ), ECM-receptor interaction pathway 


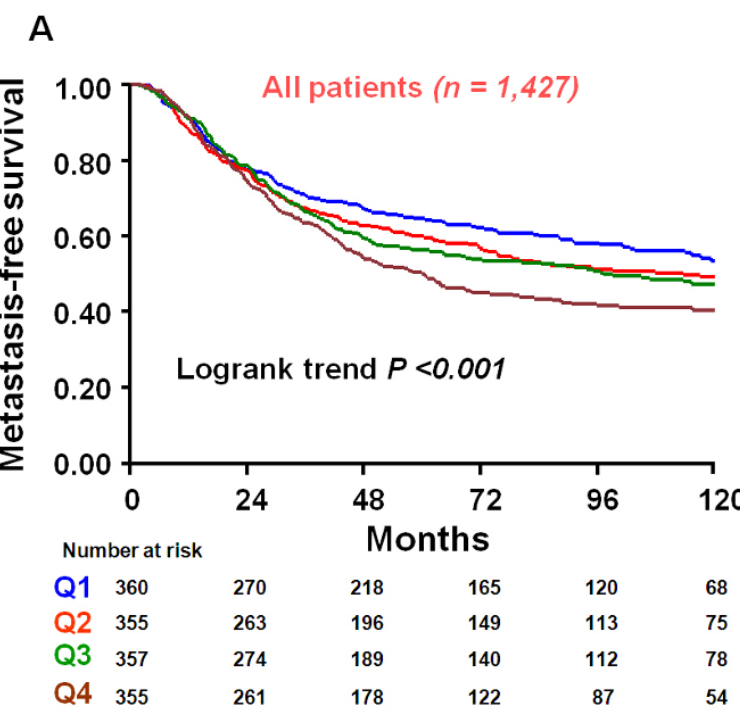

C

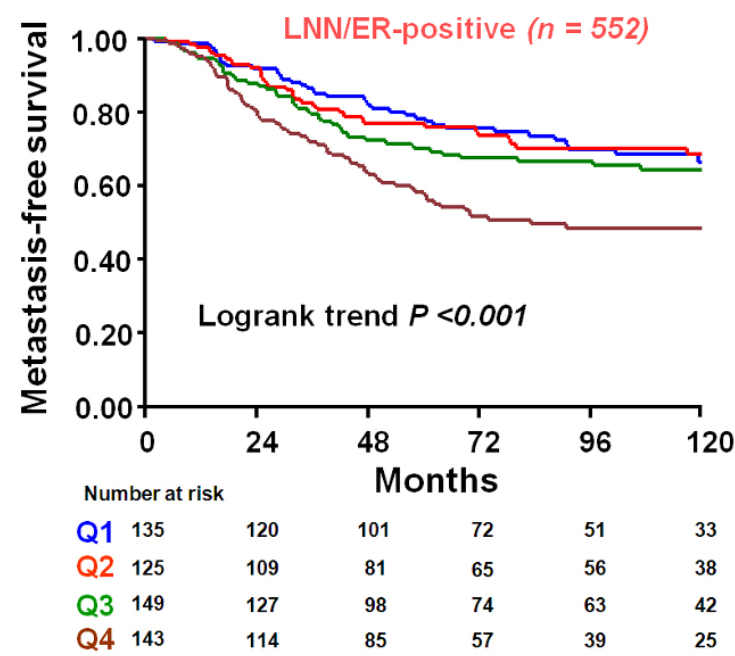

B

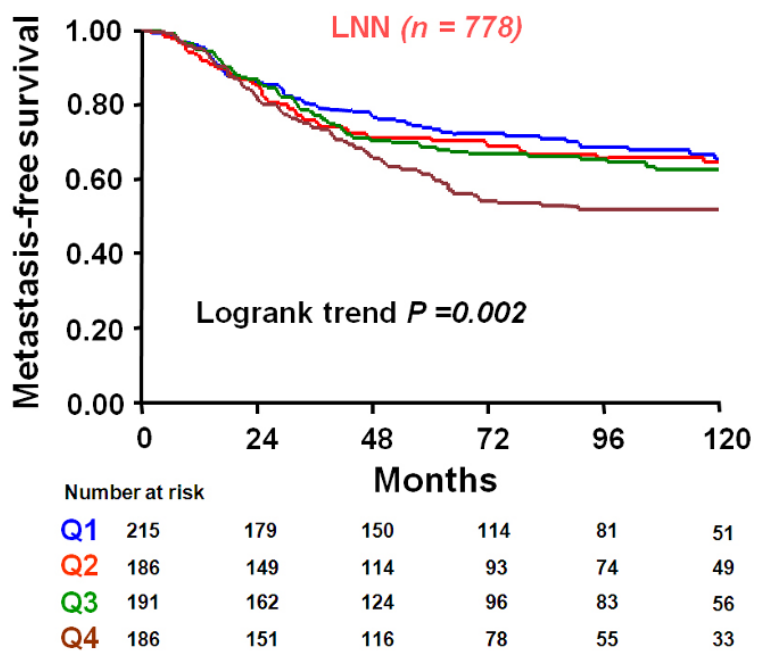

D

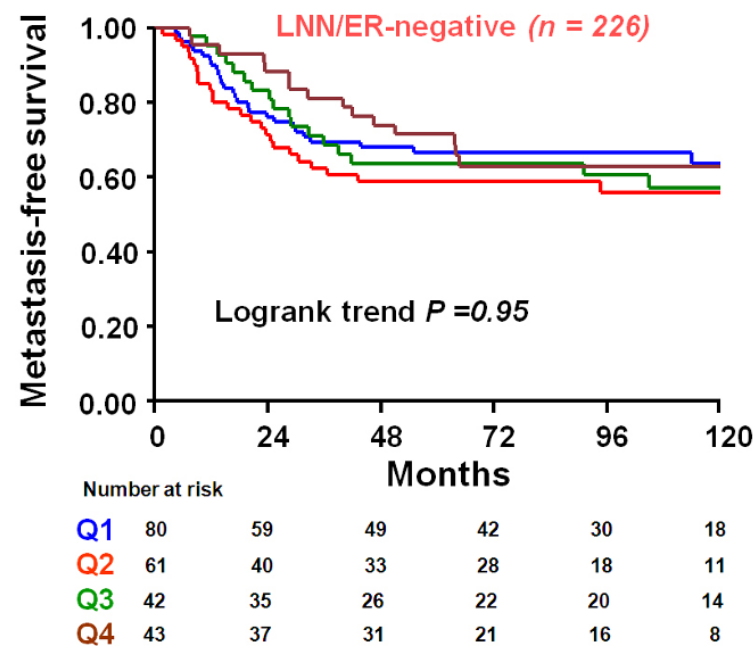

Figure 2 Kaplan-Meier survival curves presenting the association of TWIST1 mRNA expression with metastasis-free survival in: A: all 1,427 patients; B: LNN patients only, C: LNN and ER-positive patients and D: LNN and ER-negative patients. The LNN patients in this study did not receive adjuvant systemic therapy. The patients are divided into four quartiles (Q1 (low) to Q4 (high)) based on TWIST1 mRNA expression levels after normalizing these to the expression of our set of three reference genes (B2M, HMBS and HPRT1). Patients at risk at various time points are indicated.

(Fisher's exact $\left.P=9.9 \times 10^{-7}\right)$, and TGF-beta signaling pathway (Fisher's exact $P=2.6 \times 10^{-4}$ ) (Additional file 3: Table S10). In addition, GO term enrichments among TWIST1 co-expressed genes identified "cell adhesion", "extracellular structure organization" and "anatomical structure formation involved in morphogenesis" as the top three significant GO terms (level $\geq 3$; gene hits $>5$; $P$-values $\leq 0.001$ ) in the category of "biological processes", and the GO terms, "extracellular matrix" proteinaceous extracellular matrix and "extracellular matrix part" as the top three significant GO terms in the category "protein cellular components" (Additional file 3: Table S11).
To evaluate a possible TWIST1 mediated biological difference between LNN/ER-positive and LNN/ER-negative patients, we also performed pathway analyses using TWIST1 co-expressed genes $(\mathrm{n}=1,141$ positively and $\mathrm{n}=$ 498 negatively correlated genes with TWIST1, respectively, Additional file 3: Table S12A, B) measured on Affymetrix arrays from LNN/ER-negative patients $(\mathrm{n}=118)$. As observed in LNN/ER-positive patients, these analyses identified Focal adhesion and ECM-receptor interaction pathways as the two most significant pathways. But, in contrary to what observed in LNN/ER-positive patients, the TGF-beta signaling pathway was not found to be the 
Table 3 Model of uni- and multivariate analysis for metastasis-free survival in lymph-node negative and ER-positive patients $(n=552)$

\begin{tabular}{|c|c|c|c|c|c|c|c|}
\hline \multirow[t]{2}{*}{ Factors } & \multirow[t]{2}{*}{ No. patients } & \multicolumn{3}{|c|}{ Univariate } & \multicolumn{3}{|c|}{ Multivariate } \\
\hline & & HR & $95 \% \mathrm{Cl}$ & $P$-value & HR & $95 \% \mathrm{Cl}$ & $P$-value \\
\hline \multicolumn{8}{|l|}{ Age (years) } \\
\hline$\leq 40$ & 66 & 1 & & & 1 & & \\
\hline 41 to 55 & 187 & 0.97 & 0.64 to 1.49 & 0.90 & 1.05 & 0.68 to 1.64 & 0.81 \\
\hline 56 to 70 & 179 & 0.79 & 0.51 to 1.23 & 0.29 & 0.81 & 0.40 to 1.66 & 0.57 \\
\hline$>70$ & 120 & 0.59 & 0.35 to 0.99 & 0.05 & 0.59 & 0.27 to 1.28 & 0.18 \\
\hline \multicolumn{8}{|l|}{ Menopausal status } \\
\hline Premenopausal & 215 & 1 & & & 1 & & \\
\hline Postmenopausal & 337 & 0.76 & 0.57 to 1.00 & 0.05 & 0.99 & 0.56 to 1.74 & 0.98 \\
\hline \multicolumn{8}{|l|}{ Tumor size } \\
\hline $\mathrm{pT} 1, \leq 2 \mathrm{~cm}$ & 251 & 1 & & & 1 & & \\
\hline pT2, $>2$ to $\leq 5$ & 276 & 1.12 & 0.84 to 1.49 & 0.43 & 1.09 & 0.82 to 1.46 & 0.34 \\
\hline $\mathrm{pT} 3,>5+\overrightarrow{p T} 4$ & 25 & 1.62 & 0.84 to 3.11 & 0.15 & 1.92 & 0.99 to 3.75 & 0.06 \\
\hline \multicolumn{8}{|l|}{ Grade } \\
\hline Poor & 257 & 1 & & & 1 & & \\
\hline Good/Moderate & 124 & 0.53 & 0.35 to 0.79 & 0.002 & 0.56 & 0.37 to 0.85 & 0.007 \\
\hline Unknown & 171 & 1.06 & 0.78 to 1.44 & 0.70 & 1.20 & 0.87 to 1.64 & 0.26 \\
\hline \multicolumn{8}{|l|}{ PGR status (mRNA) } \\
\hline Negative & 116 & 1 & & 1 & & & \\
\hline Positive & 436 & 0.67 & 0.49 to 0.92 & 0.013 & 0.71 & 0.51 to 0.99 & 0.04 \\
\hline \multicolumn{8}{|l|}{ ERBB2 status (mRNA) } \\
\hline Negative & 475 & 1 & & & 1 & & \\
\hline \multirow[t]{2}{*}{ Positive } & 77 & 1.51 & 1.06 to 2.15 & 0.02 & 1.39 & 0.97 to 2.00 & 0.08 \\
\hline & & & & \multicolumn{4}{|c|}{ Addition to the base model } \\
\hline TWIST1 mRNA level ${ }^{\dagger}$ (Continuous) & 552 & 1.34 & 1.17 to 1.53 & $<0.001$ & 1.32 & 1.14 to 1.53 & $<0.001$ \\
\hline \multicolumn{8}{|l|}{ TWIST1 mRNA level ${ }^{\dagger}$} \\
\hline TWIST1 quartile 1 & 135 & 1 & & & 1 & & \\
\hline TWIST1 quartile 2 & 125 & 1.02 & 0.65 to 1.61 & 0.92 & 0.90 & 0.57 to 1.43 & 0.67 \\
\hline TWIST1 quartile 3 & 149 & 1.28 & 0.85 to 1.94 & 0.24 & 1.09 & 0.71 to 1.68 & 0.70 \\
\hline TWIST1 quartile 4 & 143 & 2.06 & 1.39 to 3.04 & $<0.001$ & 1.87 & 1.25 to 2.80 & 0.002 \\
\hline
\end{tabular}

† TWIST1 mRNA expression level (log-transformed after normalization to the expression of three reference genes) was separately added to base multivariate model that included the factors age, menopausal status, tumor size, grade, $E R, P G R$, and ERBB2 mRNA expression levels, tested both as a continuous variable and in four quartiles.

third most significant pathway in LNN/ER-negative patients (Additional file 3: Table S13). We also performed pathway analysis using TWIST1 co-expressed genes in all LNN patients irrespective of ER status. Analyses revealed only Focal adhesion and ECM-receptor interaction pathways as the two most significant pathways, but the TGFbeta signaling pathway was not found to be the third top significant pathway in all patients (Additional file 3: Table S14). Altogether, these data suggest that the co-expression of the TGF-beta signaling pathway with TWIST1 gene is more prominent in LNN/ER-positive cancer.

\section{Association of TWIST1 mRNA expression levels with stromal content}

The co-expression analysis suggested an association between stromal content of the tumor tissue and TWIST1 mRNA expression levels. Therefore, we studied the association of TWIST1 mRNA expression with tumor stromal content in more detail. For this, we performed LCM to separately isolate the stromal (S) and epithelial tumor cell $(\mathrm{T})$ areas from 10 breast tumor tissues $(\mathrm{n}=9$ ESR1 high, $\mathrm{n}=1$ ESR1 low) with sufficiently micro-dissectible fresh frozen tissue left. After LCM we measured TWIST1 mRNA by qRT-PCR in RNA isolated from both the stromal and the epithelial tumor cell fractions of these tissues, and normalized the expression levels to our set of reference genes. To ensure that our reference gene-set did not cause a bias in these analyses, and our LCM material was indeed enriched for stromal and epithelial cells, we also measured VIM and EpCAM (Epithelial Cell Adhesion Molecule) in these fractions (Figure $3 \mathrm{~A}$ ). In these analyses, EpCAM mRNA expression was high in the epithelial tumor cell fractions (3.4-fold, two-sided paired t-test $P=$ 0.006) and VIM and TWIST1 mRNA expression were 


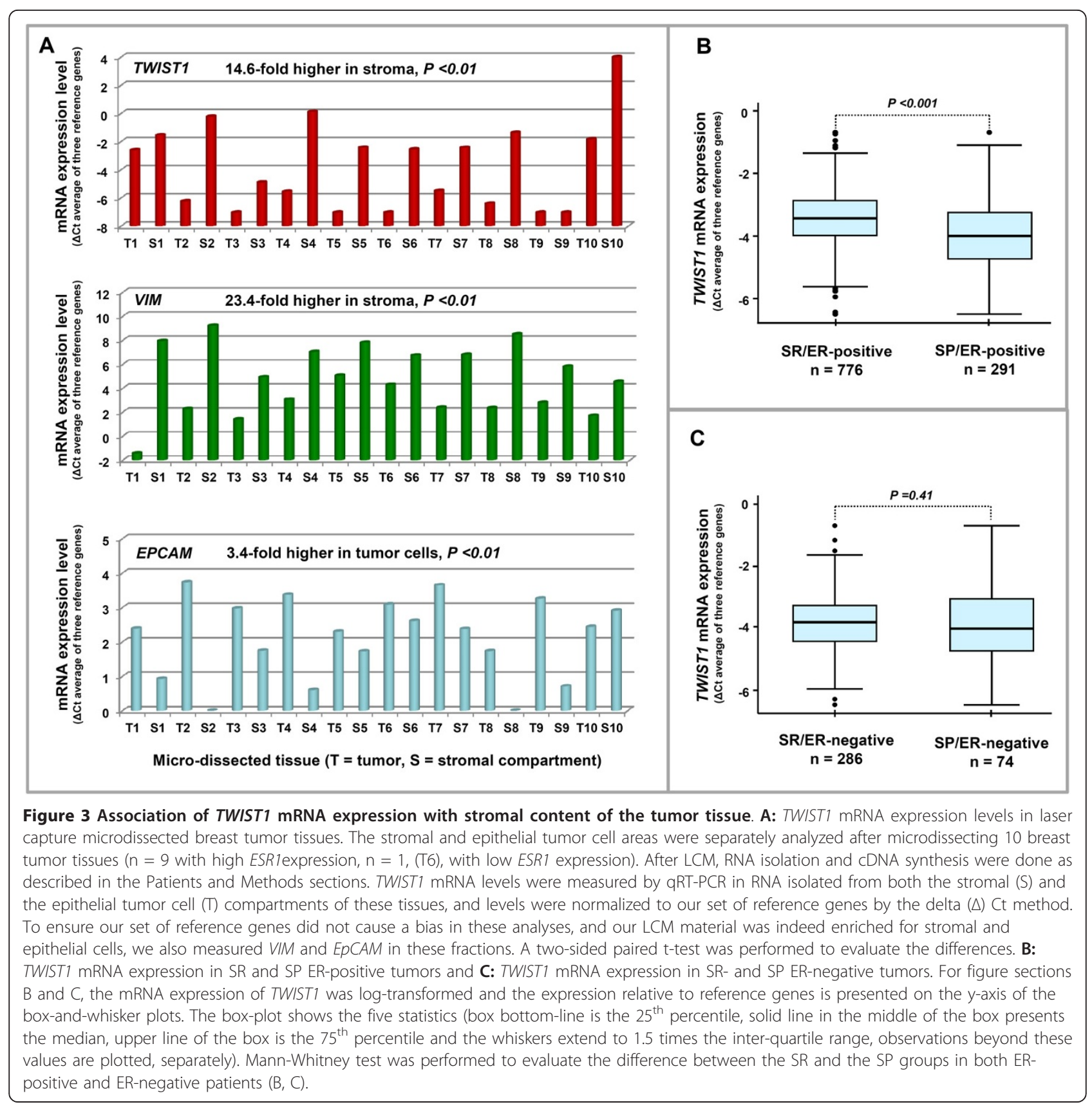

high in the stromal fractions (23.4-fold, $P=0.0001$ and 14.6 -fold, $P=0.0004$, respectively). As the prognostic value for TWIST1 mRNA expression is confined to ERpositive breast cancer, we assessed whether ER expression might be of relevance for TWIST1 mRNA expression in tumor tissues with a variable amount of stromal content. For this, we compared TWIST1 mRNA expression levels between stromal rich (SR) and stromal poor (SP) tumors in the ER-positive and ER-negative subgroups. Notably, only in ER-positive tumors, TWIST1 mRNA expression was significantly higher in SR compared with SP tumors
(Figure 3B, $\mathrm{P}<0.001$ ); in ER-negative tumors the difference was not significant (Figure $3 \mathrm{C}, \mathrm{P}=0.41$ ).

This altogether suggests that TWIST1 mRNA is predominantly expressed in the stromal compartment of breast tumor tissues. Besides addressing the issue of where TWIST1 mRNA is predominantly expressed in breast cancer tissues as described above, we also performed IHC staining to ascertain the localization of TWIST1 protein. For this, we stained 20 tumor tissues with different TWIST1 mRNA expression $(\mathrm{n}=10$ with high TWIST1 mRNA expression, $\mathrm{n}=10$ with low TWIST1 
mRNA expression). Apparently, TWIST1 protein is predominantly localized in the nuclei of both epithelial tumor cells and in almost all non-epithelial cells present in the stromal compartment of tissues, such as fibroblast cells, endothelial cells and inflammatory cells (Figure 4A, B). In these 20 tumors, TWIST1 mRNA expression levels were significantly correlated with the nuclear protein expression in tumor tissue (Spearman rank correlation, Rs $=0.61, P<0.004$ ) (Figure 4C). Additionally, tumor tissues showing weak/moderate TWIST1 protein staining were mostly ER-negative (Figure 4C).
Our data suggest that stroma of ER-positive (and not ER-negative tumors) is enriched for TWIST1. To address this in more detail, we stained 20 primary breast tumor tissues ( $n=7$ ER-negative and $n=13$ ER-positive) for TWIST1 protein. We observed that 2 out of 7 (29\%) of the ER-negative tumor tissues and 10 out of 13 (77\%) of the ER-positive tumor tissues showed moderate to strong TWIST1 protein staining in the stroma. The staining of TWIST1 in the other tumors (71\% of the ER-negatives and $23 \%$ of the ER-positives) was weak. These data based on a limited number of samples further support our qRT-PCR based findings at the protein level that the

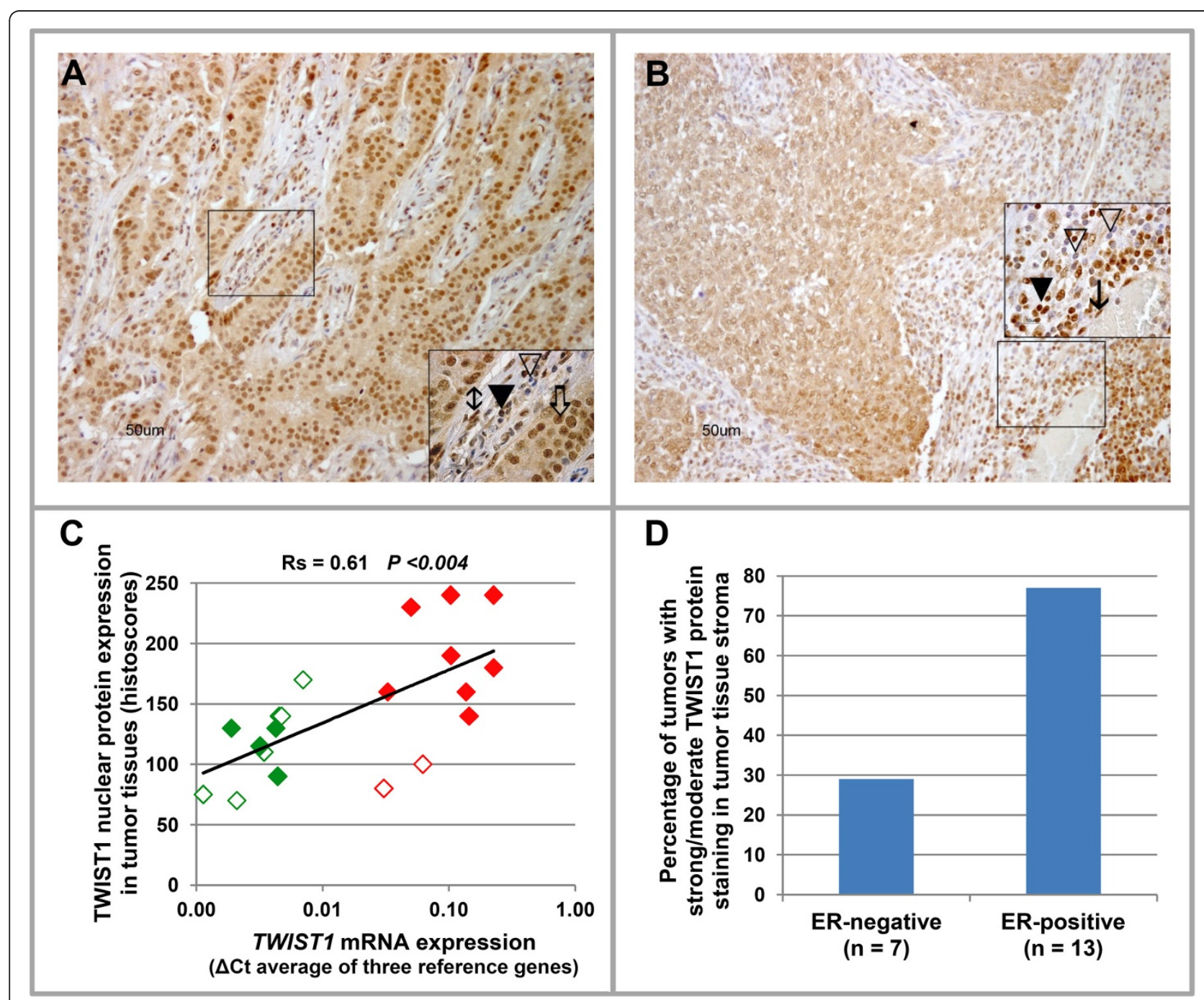

Figure 4 Representative tissues with IHC staining of TWIST1 protein. A: Strong nuclear staining of TWIST1 protein in an ER-positive tumor tissue with high TWIST1 mRNA expression. B: Weak nuclear staining of TWIST1 protein in an ER-negative tumor tissue with low TWIST1 mRNA expression. C: Correlation of TWIST1 mRNA expression and protein expression in breast tumor tissues $(\mathrm{n}=20 ; \mathrm{n}=10$ high TWIST1 mRNA expression, $\mathrm{n}=10$ low TWIST1 mRNA expression). Red and green boxes represent high and low TWIST1 mRNA expressing tumor tissues, respectively, whereas empty boxes and filled boxes represent ER-negative and ER-positive tumor tissues, respectively. Spearman rank correlation test was used to evaluate the correlation between TWIST1 mRNA and protein expression. D: Association of stromal staining of TWIST1protein with ER-positive tumor tissues. ( $\nabla=$ negative nuclei of inflammatory cells; $\mathbf{v}=$ strong positive nuclei of inflammatory cells; $\mathfrak{1}=$ strong positive nuclei of fibroblast; $\Rightarrow=$ strong positive nuclei of tumor cells; $\downarrow=$ strong positive nuclei of endothelial cells). 
stroma of ER positive tumors is enriched for TWIST1 expression (Figure 4D).

\section{Discussion}

The bHLH transcription factor TWIST1, which is essential in developmental processes, such as gastrulation, has been shown to be oncogenic in various cancers [26-33]. Functional studies pin-pointed a pivotal role for this protein in EMT, a fundamental biological process considered to be crucial for metastatic spread in various carcinomas, including breast cancer. This prompted us to analyze mRNA expression of this gene in primary breast tumors from a large retrospective cohort of patients with complete clinical follow-up and address two basic questions. First, can TWIST1 mRNA expression in breast cancer tissue predict disease progression? Second, as we had Affymetrix U133A gene-chips data available for a subset of samples $[10,11,22]$, can we reveal which biological pathways are co-expressed with TWIST1 in breast cancer?

Our current study shows that high TWIST1 mRNA expression is an independent marker of poor outcome in breast cancer patients. As TWIST1 mRNA expression was also a predictor of poor outcome in patients with LNN disease who did not receive any adjuvant systemic treatment, we may conclude that TWIST1 mRNA expression is a pure prognostic marker and is associated with the natural course of disease progression. This suggests that tumors with high expression of TWIST1 are more aggressive, a finding that fits with experimental data where overexpression of TWIST1 resulted in increased extravasation during the dissemination of tumor cells [7]. Also in line with this is the increased lymph node involvement of breast tumors exhibiting higher TWIST1 expression as observed by us and others [34]. The first seminal paper on TWIST1 in breast cancer also showed higher TWIST1 mRNA expression in infiltrative lobular carcinoma [7], which we also confirmed, though the implications of this remain unclear.

What we further unexpectedly observed was that the association of TWIST1 expression with poor prognosis was confined to ER-positive cases and not seen in ERnegative breast cancer. Similar observations were recently made by Van Nes and colleagues [21]. This group, by studying TWIST1 expression in a smaller-sized cohort using IHC on tissue microarrays, also found significantly more cumulative relapses in the ER-positive subgroup of tumors. This observation was not significant in their entire cohort, which also included ER-negative cases. Using the same antibody, we observed, in a subset of formalin-fixed specimen available from our cohort, clear nuclear TWIST1 expression. This protein expression was not only confined to the nuclei of invasive tumor cells but also present in nuclei of other cells, such as fat cells, fibroblasts, endothelial cells and inflammatory cells. Furthermore, although based on small numbers, TWIST1 protein staining was high in those specimens in which we had measured high TWIST1 mRNA expression in a matched fresh-frozen sample of the same tumor, while in specimens with low TWIST1 mRNA expression the protein staining was overall weaker or absent.

To study the potential biological mechanisms in disease progression connected to TWIST1 expression, we identified genes co-expressed with TWIST1 in LNN/ER-positive tumors from which genome wide gene expression data were available. Three related pathways were revealed. The first pathway was "Focal adhesion", which involves interaction of ECM with integrin-A and -B ligands. The second pathway, "ECM-receptor interaction", is related to ECM and involves collagen, laminin, fibronetic, tenascin and integrin- $A$ and $-B$ proteins. The third pathway is the "TGF-beta signaling". How these pathways, involving well-known cancer-related genes, are connected to TWIST1 expression in relation to disease progression in LNN/ER-positive cancer warrants functional validation. A common denominator among these three pathways, however, is their involvement in ECM remodeling. There is a growing body of evidence showing that changes in the tumor microenvironment can promote proliferation of the tumor cells and, therefore, can influence outcome of patients [35], and our data connect this to TWIST1 expression. Furthermore, our work also shows that the stroma is a significant source of TWIST transcript expression. Indeed, the current data reinforce recent observations made by Roman-Perez and colleagues after evaluating gene expression patterns in 72 breast tissue samples [36]. They identified two distinct subtypes, Active and Inactive, in the cancer-adjacent extra-tumoral microenvironment of breast tissues and demonstrated that TWIST1 was highly expressed along with other stromal associated genes, such as VIM, ADAMTS2, COL4A2, COL4A1, ITGA7 and ITGB1, in the Active subtype. This could suggest a potential involvement of TWIST1 in the activation of stroma in malignant breast tissue. Furthermore, the Active subtype was associated with expression of TGF-beta induced fibroblast activation signatures, and showed a strong association with OS among specifically ER-positive patients. Intriguingly, also in our data set, the association of TWIST1 with the TGF-beta signaling pathway appears to be more prominent in ER-positive tumors.

Another recent study also demonstrated that TWIST1 protein can be found in both compartments of malignant breast tissue, with a predominant expression in the stromal compartment [37]. More importantly, they found that, although rare in their hands, nuclear expression of TWIST1 protein in the epithelial tumor cell compartment to be associated with poor prognosis (OS). TWIST1 protein expression in the stromal compartment 
was not associated with OS, but positively associated with a positive ER or PGR status of the tumors. This mutual dependence of TWIST1 expression on the presence of a notable stromal component and an ER-positive status of the tumor tissue in our and other studies is in line with the observed prognostic value of TWIST1 in ER-positive disease only. Although our study is a correlative study and cannot reveal causality, it is intriguing and points to a novel role of TWIST1 in breast cancer.

What is surprising about our results, which associate high TWIST1 mRNA expression with poor prognosis in ER-positive breast cancer and with ECM and stromal content, is the fact that up until now the process of EMT has been more frequently assigned to ER-negative cancer and was rarely observed in ER-positive breast cancer. Also, previously studied breast cancer cell lines with clear EMT-like features were ER-negative [38]. This left us with an apparent contradiction. We, therefore, specifically explored whether markers of EMT present on gene expression arrays [11] were associated with TWIST1 expression. Of the eight markers analyzed, we found Zinc finger E-box-binding homeobox 1 (ZEB1), Zinc finger E-box-binding homeobox 2 (ZEB2), Snail2 (SNAI2), Smooth muscle actin, also known as Alphaactin-2 (ACTA2) and VIM clearly, positively correlated with TWIST1 expression $(\mathrm{Rs}=0.34,0.34,0.35,0.42$ and 0.28 , respectively; all $P$-values $<0.001$; Additional file 3 : Table S15). This does suggest, in line with the recent study of Roman-Perez and colleagues [28] that markers of EMT are co-expressed with TWIST1. However, the lack of a clear negative association of E-cadherin mRNA (CDH1) with TWIST1 mRNA expression in our data set could indicate that EMT may not be fully established. Alternatively, and more in line with our findings, is that some markers of EMT, such as Vimentin and Smooth muscle actin, are also expressed in re-activated stroma [39]. Therefore, our findings are a starting point for more functional studies to be certain about TWIST1 possible role in EMT as well as in re-activated stroma in ER-positive breast cancer.

\section{Conclusions}

In summary, we have found that the TWIST1 mRNA expression level is associated with small tumor size, invasive lobular carcinoma, stromal-rich tumors and with $P G R$ and ERBB2 (over)expression. More importantly, TWIST1 mRNA expression predicts, independently of the traditional prognostic factors, poor prognosis in patients with primary breast cancer. This association with poor prognosis is particularly observed in ER-positive disease. For this large retrospective study that involved 1,427 breast cancer specimens, we made use of all clinical material available that met the preset criteria described in Figure 1, thus reaching Level of
Evidence III (LOE-III). To reach LOE-I or -II, a prospective randomized study or pooled meta-analysis is required. Studying TWIST1 co-expressed genes, we found that ECM related pathways as well as stromal content are correlated with TWIST1 mRNA expression in LNN/ER-positive breast cancer. Functional studies are, therefore, required to determine the causal relation between these pathways and the prognostic value of TWIST1 mRNA expression in ER-positive tumors.

\section{Additional material}

\begin{tabular}{|c|}
\hline $\begin{array}{l}\text { Additional file 1: Figure S1. Log-transformed distribution of TWIST1 } \\
\text { mRNA expression levels in the entire cohort of patients. Figure S2. } \\
\text { Kaplan-Meier survival curves presenting the association of TWIST1 mRNA } \\
\text { expression with overall survival in: A: All 1,427 patients; B: LNN patients } \\
\text { only; C: LNN and ER-positive patients; and D: LNN and ER-negative } \\
\text { patients. The LNN patients in this study did not receive adjuvant } \\
\text { systemic therapy. The patients are divided into four quartiles (Q1 (low) to } \\
\text { Q4 (high)) based on TWIST1 mRNA expression levels. TWIST1 expression } \\
\text { levels are presented relative to the expression of our set of three } \\
\text { reference genes (B2M, HMBS and HPRT1). Patients at risk at various time } \\
\text { points are indicated. }\end{array}$ \\
\hline $\begin{array}{l}\text { Additional file 2: Tables S1-S8. Table S1: Model for Uni- and } \\
\text { Multivariate analysis for MFS in LNN patients ( } n=778 \text { ). Table S2: Model } \\
\text { for Uni- and Multivariate analysis for MFS in LNN \& ER-negative patients } \\
\text { ( } n=226 \text { ). Table S3: Model for Uni- and Multivariate analysis for overall } \\
\text { survival in all patients ( } n=1,427 \text { ). Table S4: Model for Uni- and } \\
\text { Multivariate analysis for overall survival in all LNN patients ( } n=778 \text { ). } \\
\text { Table S5: Model for Uni- and Multivariate analysis for overall survival in } \\
\text { LNN \& ER-positive patients ( } n=552 \text { ). Table S6: Model for Uni- and } \\
\text { Multivariate analysis for overall survival LNN \& ER-negative patients ( } n= \\
\text { 226). Table S7: Model for Uni- and Multivariate analysis for disease-free } \\
\text { survival in all patients ( } n=1,427 \text { ). Table S8: Model for Uni- and } \\
\text { Multivariate analysis for disease-free survival in LNN \& ER-positive patients } \\
\text { ( } n=552 \text { ). }\end{array}$ \\
\hline $\begin{array}{l}\text { Additional file 3: Tables S9-S15. Table S9A \& B: TWIST1 co-expressed } \\
\text { genes measured on Affymetrix U133A gene-chips in LNN/ER-positive } \\
\text { patients. Table S10: Significant pathways predicted from KEGG database } \\
\text { in LNN/ER-positive patients. Table S11: Gene ontology enrichment terms } \\
\text { from TWIST1 co-regulated genes based on their biological processes and } \\
\text { cellular components. Table S12A \& B: TWIST1 co-expressed genes } \\
\text { measured on Affymetrix U133A gene-chips in LNN/ER-negative patients. } \\
\text { Table S13: Significant pathways predicted from KEGG database in LNN/ } \\
\text { ER-negative patients. Table S14: Significant pathways predicted from } \\
\text { KEGG database in all LNN patients (both ER-positive and ER-negative } \\
\text { combined). Table S15: Correlation of TWIST1 expression with known } \\
\text { EMT markers measured on Affymetrix array in LNN/ER-positive samples (n } \\
=221 \text { ). }\end{array}$ \\
\hline
\end{tabular}

\section{Abbreviations}

ACTA2: alpha-actin-2; bHLH: basic helix-loop-helix; BM2: beta-2microglobulin; Cl: confidence interval; DFS: disease-free survival; ECM: extracellular matrix; EMT: epithelial to mesenchymal transition; EpCAM: epithelial cell adhesion molecule; ER: estrogen receptor; FDR: false discovery rate; PGR: progesterone receptor; ERBB2: erythroblastic leukemia viral oncogene homolog 2; ESR1: estrogen receptor 1; GEO: gene expression omnibus; GO: gene ontology; HER2: human epidermal growth factor receptor 2; HMBS: hydroxymethylbilane synthase; HPRT1: hypoxanthine phosphoribosyltransferase 1; HR: hazard ratio; IDC: invasive ductal carcinoma; IHC: immunohistochemistry; ILC: invasive lobular carcinoma; KEGG: Kyoto Encyclopedia of Genes and Genomes; LCM: laser capture microdissection; LNN: Iymph node-negative; LOE: Level of Evidence; MFS: metastasis-free survival; OS: overall survival; PEN: polyethylene naphthalate; Q: quartile; RT- 
PCR: reverse transcriptase polymerase chain reaction; SP: stromal poor; SR: stromal rich; TWIST1: Twist-related protein 1: also known as a basic helixloop-helix protein 38 (bHLHa38); VIM: vimentin; ZEB1: zinc finger e-boxbinding homeobox 1; ZEB2: zinc finger e-box-binding homeobox 2.

\section{Acknowledgements}

We are grateful to Joan Bolt, Vanja de Weerd, Anna van Galen and NingQing Liu for their contributions and technical support. We appreciate Gaia Schiavon for her thoughtful discussion. This study was in part financed by the Netherlands Genomics Initiative (NGI)/Netherlands Organization for Scientific Research (NWO). MR was funded by the Higher Education Commission (HEC) government of Pakistan.

\section{Authors' contributions}

AMS, JAF and JWMM designed the study. MR, JAF and JWMM wrote the manuscript. AMS performed the mRNA expression studies. MAT performed the immunohistochemistry. MR, AMS, JAF and JWMM analyzed the data. MR, MPL and MS did the statistical data analyses. All authors approved the final version of the manuscript.

\section{Competing interests}

The authors declare that they have no competing interests.

Received: 15 March 2012 Revised: 25 July 2012

Accepted: 11 September 2012 Published: 11 September 2012

\section{References}

1. Jemal A, Bray F, Center MM, Ferlay J, Ward E, Forman D: Global cancer statistics. CA Cancer J Clin 2011, 61:69-90.

2. Hanahan D, Weinberg RA: Hallmarks of cancer: the next generation. Cell 2011, 144:646-674

3. Firulli $A B$, Conway SJ: Phosphoregulation of Twist1 provides a mechanism of cell fate control. Curr Med Chem 2008, 15:2641-2647.

4. Thisse $B$, el Messal M, Perrin-Schmitt F: The twist gene: isolation of a Drosophila zygotic gene necessary for the establishment of dorsoventral pattern. Nucleic Acids Res 1987, 15:3439-3453.

5. Leptin M: Twist and snail as positive and negative regulators during Drosophila mesoderm development. Genes Dev 1991, 5:1568-1576.

6. Kress W, Schropp C, Lieb G, Petersen B, Busse-Ratzka M, Kunz J, Reinhart E, Schafer WD, Sold J, Hoppe F, Pahnke J, Trusen A, Sörensen N, Krauss J, Collmann H: Saethre-Chotzen syndrome caused by TWIST 1 gene mutations: functional differentiation from Muenke coronal synostosis syndrome. Eur J Hum Genet 2006, 14:39-48.

7. Yang J, Mani SA, Donaher JL, Ramaswamy S, Itzykson RA, Come C, Savagner P, Gitelman I, Richardson A, Weinberg RA: Twist, a master regulator of morphogenesis, plays an essential role in tumor metastasis. Cell 2004, 117:927-939.

8. Yang $\mathrm{MH}$, Hsu DS, Wang HW, Wang HJ, Lan HY, Yang WH, Huang $\mathrm{CH}_{\text {, }}$ Kao SY, Tzeng CH, Tai SK, Chang SY, Lee OK, Wu KJ: Bmi1 is essential in Twist1-induced epithelial-mesenchymal transition. Nat Cell Biol 2010, 12:982-992.

9. Mani SA, Guo W, Liao MJ, Eaton EN, Ayyanan A, Zhou AY, Brooks M, Reinhard F, Zhang CC, Shipitsin M, Campbell LL, Polyak K, Brisken C, Yang J, Weinberg RA: The epithelial-mesenchymal transition generates cells with properties of stem cells. Cell 2008, 133:704-715.

10. Yu JX, Sieuwerts AM, Zhang Y, Martens JW, Smid M, Klijn JG, Wang Y, Foekens JA: Pathway analysis of gene signatures predicting metastasis of node-negative primary breast cancer. BMC Cancer 2007, 7:182.

11. Wang $Y$, Klijn JG, Zhang Y, Sieuwerts AM, Look MP, Yang F, Talantov D, Timmermans M, Meijer-van Gelder ME, Yu J, Jatkoe T, Berns EM, Atkins D, Foekens JA: Gene-expression profiles to predict distant metastasis of lymph-node-negative primary breast cancer. Lancet 2005, 365:671-679.

12. Code of Conduct of the Federation of Medical Scientific Societies in the Netherlands. [http//www federa.org/?s=1\&m=99], In Dutch

13. McShane LM, Altman DG, Sauerbrei W, Taube SE, Gion M, Clark GM, Statistics Subcommittee of NCI-EORTC Working Group on Cancer Diagnostics: REporting recommendations for tumor MARKer prognostic studies (REMARK). Breast Cancer Res Treat 2006, 100:229-235.

14. Altman DG, McShane LM, Sauerbrei W, Taube SE: Reporting recommendations for tumor marker prognostic studies (REMARK): explanation and elaboration. BMC Med 2012, 10:51.
15. Sieuwerts AM, Meijer-van Gelder ME, Timmermans M, Trapman AM, Garcia RR, Arnold M, Goedheer AJ, Portengen H, Klijn JG, Foekens JA: How ADAM-9 and ADAM-11 differentially from estrogen receptor predict response to tamoxifen treatment in patients with recurrent breast cancer: a retrospective study. Clin Cancer Res 2005, 11:7311-7321.

16. Sieuwerts AM, Usher PA, Meijer-van Gelder ME, Timmermans M, Martens JW, Brunner N, Klijn JG, Offenberg H, Foekens JA: Concentrations of TIMP1 mRNA splice variants and TIMP-1 protein are differentially associated with prognosis in primary breast cancer. Clin Chem 2007, 53:1280-1288

17. van Agthoven T, Sieuwerts AM, Meijer-van Gelder ME, Look MP, Smid M Veldscholte J, Sleijfer S, Foekens JA, Dorssers LC: Relevance of breast cancer antiestrogen resistance genes in human breast cancer progression and tamoxifen resistance. J Clin Oncol 2009, 27:542-549.

18. Foekens JA, Peters HA, Look MP, Portengen H, Schmitt M, Kramer MD, Brunner N, Janicke F, Meijer-van Gelder ME, Henzen-Logmans SC, van Putten WL, Klijn JG: The urokinase system of plasminogen activation and prognosis in 2780 breast cancer patients. Cancer Res 2000, 60:636-643.

19. Sieuwerts AM, Look MP, Meijer-van Gelder ME, Timmermans M, Trapman AM, Garcia RR, Arnold M, Goedheer AJ, de Weerd V, Portengen $\mathrm{H}$, Klijn JG, Foekens JA: Which cyclin E prevails as prognostic marker for breast cancer? Results from a retrospective study involving 635 lymph node-negative breast cancer patients. Clin Cancer Res 2006, 12:3319-3328.

20. Umar A, Dalebout JC, Timmermans AM, Foekens JA, Luider TM: Method optimisation for peptide profiling of microdissected breast carcinoma tissue by matrix-assisted laser desorption/ionisation-time of flight and matrix-assisted laser desorption/ionisation-time of flight/time of flightmass spectrometry. Proteomics 2005, 5:2680-2688.

21. van Nes JG, de Kruijf EM, Putter H, Faratian D, Munro A, Campbell F, Smit VT, Liefers GJ, Kuppen PJ, van de Velde CJ, Bartlett JM: Co-expression of SNAIL and TWIST determines prognosis in estrogen receptor-positive early breast cancer patients. Breast Cancer Res Treat 2012, 133:49-59.

22. Smid M, Wang Y, Zhang Y, Sieuwerts AM, Yu J, Klijn JG, Foekens JA, Martens JW: Subtypes of breast cancer show preferential site of relapse. Cancer Res 2008, 68:3108-3114.

23. Benjamini $Y$, Hochberg $Y$ : Controlling the false discovery rate: a practical and powerful approach to multiple testing. J Roy Stat Soc Series $B=$ Methodological 1995, 57:289-300.

24. Tong W, Cao X, Harris S, Sun H, Fang H, Fuscoe J, Harris A, Hong H, Xie Q, Perkins R, Shi L, Casciano D: ArrayTrack-supporting toxicogenomic research at the U.S. Food and Drug Administration National Center for Toxicological Research. Environ Health Perspect 2003, 111:1819-1826.

25. ArrayTrack ${ }^{\mathrm{TM}}$ - a microarray database, data analysis \& interpretation tool. [http://www.fda.gov/ScienceResearch/BioinformaticsTools/Arraytrack/ default.htm]

26. Valsesia-Wittmann S, Magdeleine M, Dupasquier S, Garin E, Jallas AC, Combaret V, Krause A, Leissner P, Puisieux A: Oncogenic cooperation between $\mathrm{H}$-Twist and $\mathrm{N}$-Myc overrides failsafe programs in cancer cells. Cancer Cell 2004, 6:625-630.

27. Fondrevelle ME, Kantelip B, Reiter RE, Chopin DK, Thiery JP, Monnien F, Bittard $\mathrm{H}$, Wallerand $\mathrm{H}$ : The expression of Twist has an impact on survival in human bladder cancer and is influenced by the smoking status. Urol Oncol 2009, 27:268-276.

28. Elias MC, Tozer KR, Silber JR, Mikheeva S, Deng M, Morrison RS, Manning TC, Silbergeld DL, Glackin CA, Reh TA, Rostomily RC: TWIST is expressed in human gliomas and promotes invasion. Neoplasia 2005, 7:824-837.

29. Ru GQ, Wang HJ, Xu WJ, Zhao ZS: Upregulation of Twist in gastric carcinoma associated with tumor invasion and poor prognosis. Pathol Oncol Res 2011, 17:341-347.

30. Lee KW, Kim JH, Han S, Sung CO, Do IG, Ko YH, Um SH, Kim SH: Twist1 Is an independent prognostic factor of esophageal squamous cell carcinoma and associated with its epithelial-mesenchymal transition. Ann Surg Oncol 2012, 19:326-335.

31. Okada T, Suehiro Y, Ueno K, Mitomori S, Kaneko S, Nishioka M, Okayama N, Sakai K, Higaki S, Hazama S, Hirata H, Sakaida I, Oka M, Hinoda Y: TWIST1 hypermethylation is observed frequently in colorectal tumors and its overexpression is associated with unfavorable outcomes in patients with colorectal cancer. Genes Chromosomes Cancer 2010, 49:452-462

32. Gomez I, Pena C, Herrera M, Munoz C, Larriba MJ, Garcia V, Dominguez G, Silva J, Rodriguez R, Garcia de Herreros A, Bonilla F, Garcia JM: TWIST1 is 
expressed in colorectal carcinomas and predicts patient survival. PloS One 2011, 6:e18023.

33. Cosset E, Hamdan G, Jeanpierre S, Voeltzel T, Sagorny K, Hayette S,

Mahon FX, Dumontet C, Puisieux A, Nicolini FE, Maguer-Satta V:

Deregulation of TWIST-1 in the CD34+ compartment represents a novel prognostic factor in chronic myeloid leukemia. Blood 2011, 117:1673-1676.

34. Valdes-Mora F, Gomez del Pulgar T, Bandres E, Cejas P, Ramirez de Molina A, Perez-Palacios R, Gallego-Ortega D, Garcia-Cabezas MA, Casado E, Larrauri J, Nistal M, González-Barón M, García-Foncillas J, Lacal JC: TWIST1 overexpression is associated with nodal invasion and male sex in primary colorectal cancer. Ann Surg Oncol 2009, 16:78-87.

35. Bergamaschi A, Tagliabue E, Sorlie T, Naume B, Triulzi T, Orlandi R, Russnes HG, Nesland JM, Tammi R, Auvinen P, Kosma VM, Ménard S, Børresen-Dale AL: Extracellular matrix signature identifies breast cancer subgroups with different clinical outcome. J Pathol 2008, 214:357-367.

36. Roman-Perez E, Casbas-Hernandez P, Pirone JR, Rein J, Carey LA, Lubet RA, Mani SA, Amos KD, Troester MA: Gene expression in extratumoral microenvironment predicts clinical outcome in breast cancer patients. Breast Cancer Res 2012, 14:R51.

37. Soini $Y$, Tuhkanen $H$, Sironen R, Virtanen I, Kataja V, Auvinen P, Mannermaa A, Kosma VM: Transcription factors zeb1, twist and snai1 in breast carcinoma. BMC Cancer 2011, 11:73.

38. Blick T, Widodo E, Hugo H, Waltham M, Lenburg ME, Neve RM, Thompson EW: Epithelial mesenchymal transition traits in human breast cancer cell lines. Clin Exp Metastasis 2008, 25:629-642.

39. Farmer $\mathrm{P}$, Bonnefoi $\mathrm{H}$, Anderle $\mathrm{P}$, Cameron $\mathrm{D}$, Wirapati $\mathrm{P}$, Becette $\mathrm{V}$, Andre S, Piccart M, Campone M, Brain E, Macgrogan G, Petit T, Jassem J, Bibeau F, Blot E, Bogaerts J, Aguet M, Bergh J, lggo R, Delorenzi M: A stroma-related gene signature predicts resistance to neoadjuvant chemotherapy in breast cancer. Nat Med 2009, 15:68-74.

doi:10.1186/bcr3317

Cite this article as: Riaz et al:: High TWIST1 mRNA expression is associated with poor prognosis in lymph node-negative and estrogen receptor-positive human breast cancer and is co-expressed with stromal as well as ECM related genes. Breast Cancer Research 201214 R123.

\section{Submit your next manuscript to BioMed Central and take full advantage of:}

- Convenient online submission

- Thorough peer review

- No space constraints or color figure charges

- Immediate publication on acceptance

- Inclusion in PubMed, CAS, Scopus and Google Scholar

- Research which is freely available for redistribution

Submit your manuscript at www.biomedcentral.com/submit 